\title{
Using Teacher -SWOT Analyses as a Tool for Pedagogic Practice Efficiency: The Case of Some Selected English-Speaking Primary Schools in the Diamare Division, Far North Region of Cameroon
}

\author{
Bachir Bouba*, Galy Mohamadou, Noah Abunghang Asuanteh \\ Higher Teacher-Training College - Maroua
}

*Corresponding Author: Bachir Bouba, Higher Teacher-Training College - Maroua

\begin{abstract}
This article is aimed at studying the relationship between SWOT analyses and pedagogic practice and to show that pedagogic practice efficiency can be achieved through these analyses. This descriptive study made use of a questionnaire with semi-open ended questions to gather information from 98 teachers in the Diamare Division. The qualitative data collected was summarised and presented according to the category of responses. The TOWS matrix table was used to analyse the information by applying content analysis. After the analyses, it came out that $62.2 \%$ of teachers in the Diamare Division carry out SWOT analyses which have enhanced their pedagogic practice efficiency. Thus, teachers SWOT analyses enhance pedagogic practice efficiency.
\end{abstract}

Keywords: Relationship, SWOT analyses, pedagogic practice, efficiency, TOWS matrix.

\section{INTRODUCTION}

The teacher is the main catalyst in the educational sector of every nation in general and Cameroon in particular. Section 37 (1) of law no 98/004 of 14 April 1998 states that the teacher shall be the principal guarantor of the quality of education. For the teacher to be efficient in guaranteeing the quality of education, he or she has to be an educator who is ready for self-evaluation. Tsafack (2001.p, 27-28) says, a teacher must be an educator by vocation. A vocation itself is an appeal, a calling, the aptitude for a well-defined task, trade or profession. The educator's mission requires free and complete devotion to their task. In practice, a person who has teaching as a vocation tends to value the profession more than anything else. This is reflected in the love for the teaching, preference, the attachment to and constant evaluation of the pedagogic practice so as to be efficient. Every now and then, we teachers need to look to ourselves and evaluate all the aspects of our pedagogic practice, both the good and the bad. If teachers make self-assessment a routine, they will seek developing patterns and discover where strengths and weaknesses lie.

Knapp (1982) quoted by Nkong .M.V.M (2017.p.78) opines that teachers want an evaluation system that encourages professional development, acknowledges the difficulties and complexities of teaching and that which protects teachers' rights. The form of teacher evaluation that promotes teachers' rights is self-evaluation. When a teacher evaluates their own pedagogic practice because he/she has gained self-awareness, the friction that usually exists between teachers and external evaluators during teacher evaluation will be limited and the rights of the teacher will be protected.

In MINESEC (2013. p.113), Syllabuses for T.T.C. one-year course, preview self-evaluation as a topic in all the courses on didactics. This is to equip the student-teachers with the skills to do self-evaluation. Upon graduation, the teacher is expected to have developed the skills of self-evaluation. According to Robison (198.p.116), for one to keep improving as a teacher, one has to evaluate oneself from time to time. In the self-evaluating task, the first thing to do is to set a norm or standard. Self-evaluation is looking at one's career development and learning in order to determine what has improved and what areas still need improvement. It usually involves comparing a "before" situation with a current situation. Lyan .L.K (1993.p.9) says that self-evaluation reduces the threat and anxiety that often exist in the supervisor-supervisee situation. When self-evaluation is done appropriately, it leads to teacher efficiency because minor adjustments will be made.

From Tsafack (2001) and Wanjala (2012) we can deduce that, a teacher's pedagogic efficiency is measured by the way the they pay adequate attention to learners, their commitment to their tasks, 
their level of lesson preparation, number of different lessons taught, the marking of learners exercise books, utilization of the teaching-learning time, classroom management strategies, evaluation strategies on students and learner-centred strategies, participation in research, the learners' performances and remediation. Added to this list include the mastery and application of the appropriate teaching approaches, the evaluation of learning out comes which according to Eni, Woyen and Tata (2012, p.8) quoted by Asuanteh (2017.p.24) is aimed at reducing failure, fostering collective promotion and the rate of programme coverage per sequence.

\section{Statement Of The Problem}

Section 37 (1) of law no 98/004 of 14 April 1998 points out that, the teacher shall be entitled to continuing training. This in-service or continuing training is done through workshops, seminars, action research, distance education, programmed instruction and the setting up of teachers' resource centres. It is idealistic that full participation in these activities will enhance teacher pedagogic practice efficiency. An observation on the field reveals that seminars and teacher inspection are organised at the level of the inspectorate of basic education, the divisional and the regional delegations to promote professional development for pedagogic efficiency in the class room. Tambo (2003) hold that inservice training is a means of teacher professional development but teachers are often reluctant or unwilling to contribute financially to attend seminars. Tambo (2003) says the need for teacher resource centres to promote professional development is well accepted by practicing teachers but an observation of the existing resource centres at the provisional (regional) and national level reveals that teachers do not adequately use the existing resources. Looking at this, one notices that an external force that is teacher inspection, teacher evaluation, pedagogic seminar, workshop, and provision of in-service training has not really enhanced pedagogic efficiency. This draws our attention to self-evaluation as the inner force which can enhances professional development for pedagogic efficiency. For a teacher to carry out self-evaluation, they must be intrinsically motivated as put forth by the theory of selfdeterminism.

The self-determination theory (SDT) is a macro theory of human motivation and personality that is concerned with people's inherent growth tendencies and innate psychological needs and the motivation behind choices people make without external influence and interference. SDT focuses on the degree to which an individual's behaviour is self-motivated and self-determined, Deci and Ryan(1985). SWOT analyses is motivated by intrinsic motivation rather than extrinsic motivation. To Tryan \& Connell, (1989) and Vallerand, (1997) cited by Deci \& Ryan (2000.p.68) the term extrinsic motivation refers to the performance of an activity in order to attain some separable outcome and, thus, contrasts with intrinsic motivation, which refers to doing an activity for the inherent satisfaction of the activity itself.

In this study we are putting forth the thesis that teacher-SWOT analyses are the means through which a teacher can foster their pedagogic efficiency as an end product of professional development. Thus, do teacher-SWOT analyses enhance teacher pedagogic practice efficiency in the classroom?

\subsection{Research Question}

Do teacher-SWOT analyses enhance teacher efficiency?

\subsection{Objectives}

To verify whether teacher-SWOT analyses enhance teacher efficiency.

\section{HYPOTHESES}

Teacher-SWOT analyses enhance teacher efficiency.

\subsection{Rationale}

The raison d'être for this study lies in the fact that much is done by educational authorities and administrators for teacher professional development so that the teacher can be efficient in their pedagogic practices in the classroom but the teachers do not seem to be involved, so there is no visible change. This study is out to proof that what can make a teacher develop professionally efficient in his or their pedagogic practice is not in what the educational authorities do but it is in the hands of the teachers themselves. That is, it is only when the teacher will consciously do an evaluation of his or her pedagogic practice, then can they make concrete adjustments which will spur him or her to seek 
avenues of professional development so as to be efficient in his or her pedagogic practice. We want to exploit the SWOT analyses which is an instrument for self-evaluation and helps in both short term and long term decision making to carry out adjustment with respect to actions to perfect a system or career. The teacher needs to carry out SWOT analyses of the strengths, weaknesses, opportunities and threats in his or her pedagogic practice so as to do adjustments and therefor become efficient in the pedagogic practice in the classroom.

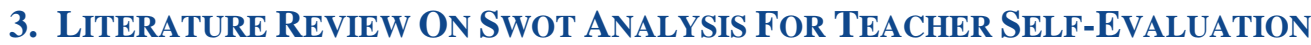

SWOT (Strengths, Weaknesses, Opportunities and Threads) is a powerful and most often a highly successful technique with respect to organizations, and can also be valuable when applied to individuals and their careers (David, 1997). Strengths stand for the characteristic of the individual that give him or her an advantage over others. That is positive tangible and intangible attributes, internal to an individual. With respect to weaknesses, they are characteristics that place an individual at a disadvantage relative to others. For opportunities, we see them as external attractive factors that represent reasons why you are likely to grow. Finally, the threats which are external elements in the environment that could cause trouble for an individual are external factors beyond an individual's control.

Kamelia Gulam, (2015), says the SWOT analyses is a technique that enables an individual to move from everyday problems and traditional strategies to a fresh prospective. SWOT analyses are aimed at helping an individual to understand their strengths and weaknesses and to promote strategic thinking. SWOT analyses help the teacher plan their short- and long-term goals, develop action plans to meet those goals, and identify any obstacles and opportunities that might be associated with them.

\subsection{Practical Cases of Swot for Teachers}

Naga Raju (2014) presented an elaborate SWOT for teachers in which two things are pointed out. The first thing is the eight level of the teacher's perception about him/herself with respect to their pedagogic practice and the second is a checklist to analyse his practice.

As regards the teacher's personal perception, the teacher perceives tasks in the following ways:

- I won't do it; at this level, the teacher is self-defeated and ready to give up or remain in his/her old practice. The perception of the task is negative and the teacher does no effort to improve.

- I can't do it; at this level, the teacher perceives the task as difficult but shows the interest to overcome the challenge. A conscious teacher who wants to grow professionally takes a challenge to overcome or to do it with intension of surmounting the challenge.

- I want to do it; this is positive because the teacher is determined to carry out the specific task no matter the nature of its complexity. The teacher is ready to carry out the task, make his/her mistakes and look for ways to correct the mistakes to be an efficient teacher.

- How do I do it? The teacher has all the zeal and looks for ways to carry out the task or put into practice the recommended pedagogic practice. The teacher has the fear of failure so he/she does everything to ensure that he/she surpasses the fear to implement the practice accurately.

- I will try to do it; this teacher has the will to do and to perfect his practice. When there is the will to do, the teacher will definitely seek for the how to do.

- I can do it; this is very positive and shows that the teacher has overcome all his constraints and ready to perform.

- I will do it; this shows some confidence in the teacher. The teacher is sure of what he/she wants to do and is ready to do it.

- Yes I did it; this signifies achievement. The teacher has evaluated his practice over and over and perfected it in such a way that he/she can say with confidence that he/she has overcome the challenges and perfected on his pedagogic practice and as such he/she can be a point of reference.

The next thing that Raju (2014), presents is a check list for teachers to do SWOT analyses. The check list for strengths is:I have a passion for teaching; I have good interpersonal skills; I have the teachers' grade one certificate; I have a degree in education; I have good critical or analytical skills; I have 
plenty of work experience; I am good with public speaking; I am financially sound; I am young and healthy and I have a supportive spouse

According to Drucker (2005, p. 102), a teacher needs to put him or herself where their strengths can produce results. Strengths identify what one does better than others in the school. These strengths could include one's work experience, academic background, specific technical competencies, personal characteristics and one's language skills. Once a person has identified these key attributes, they should figure out how these attributes will help them to make a success of this specific position

Collins (2001, p. 84) points out that, in assessing one's weaknesses, it may be important to keep in mind the Stockdale paradox which suggests that individuals be ruthlessly honest in identifying their weaknesses yet maintain a faith that they can achieve their personal goals. Rand (1957 p. 794), says that once a person has a picture of their weaknesses, they can start working on ways to improve on them. Raju (2014) continues to point out the following weaknesses:I have no or little relevant experience; I am lazy and suffer from procrastination; I lack concentration or attention span; I have limited subject knowledge; I lack stress management skills; I am poor at dealing with conflicts; I am low in self-esteem and I leave far from school

Concerning opportunities in Raju (2014) checklist, the following points are highlighted: I have a job offer in a school which suits my temperament better; Eventually I could go for further studies; I have been offered a scholarship for my studies; our school offer free 'WiFi' on campus; we have a wellequipped library in school; many new educational institutions are opening in my locality; my children are offered free education at school and our institution offers an annual gold medal for the best teacher

Collins (2001, p. 84) also points out that opportunities are the possibilities that an individual might take advantage of and pertains to forces in a person's operating environment that might increase demand for what the person can provide or allows the individual to provide more effectively.

Lastly, on the threats, Collins $(2001$, p. 84) continues that threats are the conditions, barriers, or constraints that limit or those that are harmful to achieving a person's goals or objective. What has typically been found to be effective, based on SWOT input, is a strategy that takes advantage of the person's opportunities by employing his or her strengths and by proactively addressing threats by correcting or compensating for weaknesses. It is important to recognize that strengths can be viewed as weaknesses and opportunities can contain hidden threats as well. In the same light Raju (2014) has brought forth a checklist for threats as follows: we have no opportunities for further studies in our school; I have a heavy work load; I need to sign a contract if I take a new job; my school has no good library; my family depends on my salary I cannot take a risk; the new syllabus has chapters I am not comfortable with and this place is quite expensive.

The most important thing is the desire to grow professionally and be efficient in your pedagogic practice. Summarily, the intent of SWOT is to capitalize on the strengths, address weaknesses, take full advantage of opportunities, and minimize the impact of threats so as to develop professionally and become efficient in the classroom.

\subsection{Pedagogic Practice Efficiency}

A teacher has a task to carry out in the class so as to enable the learners to maximize learning. These activities termed pedagogic practices are practices which educators possess that facilitate and promote children's learning. According to Margaret .C. (1997a.p.153), some pedagogic practices include the planning of the lessons, the organization of the lesson, including lesson structure and pupil groups, assessment of pupils and follow up activities. These practices are shaped by research, reflections, documentation and learning. This implies that the teacher's initial training and continuous training in the field helps to sharpen the teacher's pedagogic practice to render the teacher efficient. Tsafack (2001, p.185) hold that teachers efficiency is measured by the way the teacher pays adequate attention to learners and the teachers commitment to their task.

\section{Methodology}

\subsection{Research Design}

The research design used in this study is the descriptive design which has to deal with the investigations of current events, specifically, educational issues or practices, behaviours and attitudes 
of learners. We explored literature related to the topic and described how teacher carry out selfevaluation for pedagogic efficiency is currently being practiced in primary schools in Diamare division in the Far North Region of Cameroon. The survey design was used where by a questionnaire was administered to teachers and analysed using the SWOT matrix.

\subsection{Sample Population}

The population under study is made up of 100 teachers that is 34 male teachers and 66 female teachers from the thirteen English speaking primary schools in Diamare Division.

\subsection{Instrument of Data Collection}

The main instrument for data collection was the open-ended questionnaire because it gives room for the subject to respond freely. It aids in getting information about the subject from a third party and also orientates the responses towards the expected outcome. We also used the non-participant observation to get first-hand information which the questionnaire could not give.

\subsection{Method of Data Presentation and Analyses}

The TOWS matrix was used to verify the hypothesis. This involves determining the objectives, creating the grid, labelling the boxes, adding the entries and drawing conclusion. We used the SWOT matrix because it is one of the frequently used instrument for content analyses in social science and it is also an instrument for analysing qualitative information.

\section{Computation Of Results}

\subsection{Demographic Information}

Table1. Sex

\begin{tabular}{|l|l|l|l|l|}
\hline Sex & Tally & Percentage & \multicolumn{2}{|l|}{ Rate of SWOT analyses } \\
\cline { 4 - 5 } & & & Frequency & Percentage \\
\hline Male & 40 & $\mathbf{4 0 . 8} \%$ & $\mathbf{3 6}$ & $\mathbf{9 0} \%$ \\
\hline Female & 58 & $\mathbf{5 9 . 2} \%$ & $\mathbf{2 5}$ & $\mathbf{4 3 . 1 \%}$ \\
\hline & 98 & $\mathbf{1 0 0 \%}$ & $\mathbf{6 1}$ & $\mathbf{6 2 . 2} \%$ \\
\hline
\end{tabular}

This return table which is strictly based on sex distribution of respondents shows that $40.8 \%$ males and $59.2 \%$ females responded. These differences in sex influences the SWOT analyses of teachers. The male teachers are more concerned with their SWOT analyses than the females. The table reveals that 90\% of males do their SWOT analyses while only $\mathbf{4 3 . 1} \%$ of females out of the 58 who responded actually took time to carry out their SWOT analyses. A total of $62.2 \%$ teachers according to sex distribution do SWOT analyses.

Table2. Age range

\begin{tabular}{|l|l|l|}
\hline Age range & Tally & Percentage \\
\hline 20-30 years & 21 & $21 \%$ \\
\hline 31-40 years & $\mathbf{4 0}$ & $\mathbf{4 2} \%$ \\
\hline 41+ years & 37 & $37 \%$ \\
\hline & 98 & $100 \%$ \\
\hline
\end{tabular}

The age table shows that $21 \%$ of the teachers fall within the age range $20-30$ years, $42 \%$ between the age range 31-40 years and 37\% ranges from 40 years and above. The age did not have a sharp influence on SWOT analyses for teachers because teachers of each age range are involved.

Table3. Marital status

\begin{tabular}{|l|l|l|l|l|}
\hline Status & Tally & Percentage & \multicolumn{2}{|l|}{ Rate of SWOT analyses } \\
\cline { 4 - 5 } & & & Frequency & Percentage \\
\hline Married & $\mathbf{7 0}$ & $\mathbf{7 1 . 4} \%$ & $\mathbf{4 5}$ & $\mathbf{6 4 . 2} \%$ \\
\hline Single & $\mathbf{2 8}$ & $\mathbf{3 8 . 6} \%$ & $\mathbf{2 4}$ & $\mathbf{8 5 . 7} \%$ \\
\hline & $\mathbf{9 8}$ & $\mathbf{1 0 0 \%}$ & $\mathbf{6 9}$ & $\mathbf{7 0 . 4} \%$ \\
\hline
\end{tabular}

It was also noticed that marital status played a role on teacher-SWOT analyses. This table on marital status of respondents, shows that $71.4 \%$ of the respondents are married while $38.6 \%$ are singles. The results show that single teachers are more concerned with their SWOT analyses than the married 
teachers. The information presented shows that $85.7 \%$ single teachers do SWOT analyses. Making a match to sex distribution, the female singles are imbedded in this group. The table also shows that $64.2 \%$ of married teachers do SWOT analyses. This $64.5 \%$ of the married teachers include the $90 \%$ males indicated at the level of sex distribution. In a whole, according to status, $70.4 \%$ of teachers do SWOT analyses in the Diamare Division.

Table4. Teaching experience

\begin{tabular}{|l|l|l|l|l|}
\hline Experience & Tally & Percentage & \multicolumn{2}{|l|}{ Rate of SWOT analyses } \\
\cline { 4 - 5 } & & & Frequency & Percentage \\
\hline 0-5 years & 4 & $4 \%$ & 00 & $\mathbf{0 0}$ \\
\hline 6-10 years & 61 & $\mathbf{6 2} \%$ & $\mathbf{5 6}$ & $\mathbf{9 1 . 8 \%}$ \\
\hline $11+$ years & $\mathbf{3 3}$ & $\mathbf{3 4 \%}$ & $\mathbf{1 0}$ & $\mathbf{3 0 . 3} \%$ \\
\hline & $\mathbf{9 8}$ & $\mathbf{1 0 0} \%$ & $\mathbf{6 6}$ & $\mathbf{6 7 . 3} \%$ \\
\hline
\end{tabular}

Experience has an influence on the rate at which teachers do SWOT analyses. Teachers between 6-10 years of experience ( $62 \%$ ) are versed with SWOT analyses indicated by $91.8 \%$ with a few teachers having more than 11 years teaching experience represented by $30.3 \%$.

\section{Summary Of The Response Of Teachers Concerning The Awareness Of Swot For TEACHERS.}

To gather information on teacher-SWOT analyses in order to infer how it influences pedagogic practice efficiency of teachers in the Diamare Division, a questionnaire of twelve semi-open questions was administered to100 teachers and 98 teachers responded. The questions were presented in a way that four were to identify the teachers SWOT, four to find out how each teachers makes use of his or her SWOT to improve pedagogic practice and four were to verify how they analyse their SWOT based on the TWOS matrix to be efficient in their pedagogic practice. We selected the ideas that were common to the teachers on each aspect investigated and also relevant to teachers SWOT as guided by literature.

As far as the teachers strengths are concerned, the strengths of the teachers in the Diamare Division can be summarized into eight items namely professional diploma; interpersonal skills (communicate,solve conflicts, tolerance, disciplined, sociable and collaborative); creativity and enthusiasm for the job, skill on the production of teaching aids; ability to acquire and transmit knowledge; love and passion for teaching; professional consciousness and the ability to transform the minds of learners.

In verifying how these strengths help the teachers, it emerges that the teachers use these strengths to organise their class well; plan their lessons well; do more research on new methods of teaching; exercise patience with learners using diverse teaching aid and methods to make them succeed; exercise self-confident in class when teaching and create a friendly relationship with learners to follow them up academically. From this, it is glaring that teachers in the Maroua municipality carryout SWOT analyses.

From The responses gathered, the weaknesses of these teachers include lack of patience with slow learners; discouragement and demotivation when learners are not attentive; anger which erupts when the learners do not respond to the lessons proportionately to the energy put in; lack of skills in technology; large class size which makes class management difficult; the reluctance to draw lesson notes; the inability to respect time so as to teach the required number of lessons; the reluctance to do extra effort to go beyond the curriculum, disorganised and lazy; easy defeat in the face of challenging pedagogic practices and fear of failing to produce desired results. These aspects of weaknesses have a negative bearing on the teachers' pedagogic practices because weaknesses come from within. This notwithstanding, teachers do not just allow these weaknesses to destroy them but they try to use the weaknesses to improve on their pedagogic practice.

From the findings, it came out that teachers exploit their weaknesses to ameliorate their pedagogic practice in the following ways: they press on for the sake of the few learners who show interest knowing the others will catch up with time; they challenge themselves to learn ICT and educational technology to meet up with the exigencies of the New Curriculum for primary school in Cameroon; they try to use teaching aids to illustrate so as to overcome the language barrier and elicit better 
understanding; they overcome anger with love, that is they try to understand the learners need help express love which make them see that the learners will improve; they do efforts to plan extra activities to help the backward and slow learners to avoid failure and build the hope that the learners would do better.

With regards to the teachers' opportunities, nine capital opportunities which keep the teachers in the Diamare Division motivated in their pedagogic practice were regrouped notably the availability of opportunities for further studies to acquire more or higher certificates engendered by the presence of the University of Maroua; the opportunity to attend in-service pedagogic seminars especially as the Diamare Division is at the Regional headquarters of the Far North Region, the opportunity to be appointed into administrative post; the opportunity to write textbooks and sell to earn extra-money; there is assess to text books and didactic materials especially as Diamare Division is a university milieu dotted with different faculty libraries and free Wifi connection; the opportunity to be reclassified to a higher grade as a result of further studies; the opportunity to swap to any of the ministries of education; establish contact with parents from different walks of life and forums for exchange of knowledge like What Sapp groups and teacher associations.

These opportunities which are an external force serve as a motivation to the teachers and they make the following gains out of these opportunities; they keep building themselves academically; do more research to acquire knowledge; study about learners and teach according to their age and intellectual development; they learn more economical efficient ways of class management and remediation; keep advancing in education as they learn new methods and techniques of teaching, lesson planning, follow up of learners and how to carryout action research; they have direct access to ask questions during seminars for clarification on the methods of teaching; they plan good lessons, learn more efficient teaching strategies, learn effective and efficient evaluation and remediation techniques. All these help them to be more efficient in their pedagogic practice.

The last main item on the teachers SWOT analyses is their threats. Threats like opportunities are external forces which play against teachers' pedagogic efficiency. Here the teachers pointed out ten threats. These are: attack from parents and learners; bias appointments; poor carrier management; threat from colleagues and administration; poor infrastructure; overcrowded classes; the pressure to implement policies which do not fit in their context of teaching; the arrest and intimidation of teachers by administrative authorities out of education; parents pose to challenge teachers in their practice and criticisms from colleagues, learners and the administration. Teachers do not only get scared by these threats but use them as a means to step up their pedagogic practice.

In terms of ways by which teachers have used their threats to improve their pedagogic practice, the teachers expressed that these threats boost their pedagogic practice in the following ways: they try as much as possible to teach what is correct to learners; do self-discipline to avoid confrontation with learners and parents; give moral lessons to the learners always to create a conducive atmosphere; do group work as a technique to teach in the overcrowded classes; avoid problematic parents by giving in the best of their pedagogic practice; concentrate on teaching and do not have regard for the poor carrier management and focus on the teaching objectives so as to achieve the most.

From this presentation of results from the respondents, we can deduce that teachers in the Diamare Division do SWOT analyses although only a few of them do it intentionally. As seen from the presentation of the responses per demographic information; sex, marital status and teaching experience influence the rate at which teachers do SWOT analyses. The male teachers are more susceptible to SWOT analyses especially during their six to ten years of experience. They become conscious of their pedagogic practice after the fifth year of teaching. As for the females, it shows that those who do a SWOT analyses are mostly the singles. These single females are motivated by the opportunities that are present in their service.

Table5. Data analyses and discussion

\begin{tabular}{|c|c|c|}
\hline & STRENGTHS & WEAKNESSES \\
\hline Internal factors & $\begin{array}{l}\text {-my professional diploma } \\
\text {-interpersonal } \\
\text { (communicate,solve conflicts, } \\
\text { tolerance, disciplined, sociable and }\end{array}$ & $\begin{array}{l}\text { lack of patience with slow learners } \\
\text {-discouraged and demotivated when } \\
\text { learners are not attentive } \\
\text {-easily angered when the learners do }\end{array}$ \\
\hline
\end{tabular}




\begin{tabular}{|c|c|c|}
\hline Exte & $\begin{array}{l}\text { collaborative) } \\
\text {-love, creativity and enthusiasm for } \\
\text { the job } \\
\text {-skill on the production of teaching } \\
\text { aids } \\
\text {-ability to acquire and transmit } \\
\text { knowledge } \\
\text {-love and passion for teaching } \\
\text {-professional consciousness } \\
\text {-the ability to transform the minds } \\
\text { of learners }\end{array}$ & $\begin{array}{l}\text { not respond to the lessons } \\
\text { proportionately to the energy put in. } \\
\text { - lack skills in technology } \\
\text {-the large class size makes class } \\
\text { management difficult } \\
\text {-do not draw lesson notes } \\
\text {-do not do extra effort to go beyond } \\
\text { the curriculum } \\
\text {-disorganised and lazy } \\
\text {-easily defeated by challenging } \\
\text { pedagogic practices } \\
\text {-fear of failing to produced desired } \\
\text { results }\end{array}$ \\
\hline OPP & SO Strategy & WO Strategy \\
\hline $\begin{array}{l}\text { the opportunity for further } \\
\text { studies to acquire more } \\
\text { certificates } \\
\text {-the opportunity to attend in- } \\
\text { service pedagogic seminars } \\
\text {-the opportunity to be } \\
\text { appointed into administrative } \\
\text { post. } \\
\text {-the opportunity to write } \\
\text { textbooks and sell } \\
\text {-assess to text books and } \\
\text { didactics materials } \\
\text {-the opportunity to be } \\
\text { reclassified to a higher grade } \\
\text {-the opportunity to swap to } \\
\text { any of the ministries of } \\
\text { education } \\
\text {-establish contact with parents } \\
\text { from different walks of life } \\
\text {-forums for exchange of } \\
\text { knowledge }\end{array}$ & $\begin{array}{l}\text { - the academic and professional } \\
\text { diplomas serve as a spring board } \\
\text { for further studies } \\
\text {-maintain zeal and duty } \\
\text { consciousness to merit promotion } \\
\text { and appointment } \\
\text { - Experience empowers research } \\
\text { and sharing of knowledge through } \\
\text { the writing and publication of } \\
\text { books for sale. } \\
\text { - use interpersonal skills like } \\
\text { sociability and communication to } \\
\text { interact and participate in various } \\
\text { in-service training programme to } \\
\text { improve on pedagogic practice } \\
\text {-exploit the passion for teaching to } \\
\text { go for further professional training } \\
\text { programmes in the carrier. }\end{array}$ & $\begin{array}{l}\text { - to avoid laziness, create } \\
\text { opportunities to learn } \\
\text {-to overcome discouragement, seek } \\
\text { for transfer or further studies to have } \\
\text { a change of environment } \\
\text {-the reluctance to take challenges is } \\
\text { overcome by the aspiration to gain } \\
\text { promotion which compels the } \\
\text { acceptance of some difficult and } \\
\text { challenging pedagogic practices to } \\
\text { please the administration. } \\
\text {-exploit any opportunity to attend } \\
\text { pedagogic seminars for the } \\
\text { acquisition of more knowledge in } \\
\text { other to overcome fear of not } \\
\text { producing desired results. } \\
\text {-participate in pedagogic workshops, } \\
\text { in-service training programmes } \\
\text { facilitates the overcoming of } \\
\text { weaknesses. } \\
\text {-seek for positions like class master } \\
\text { or pedagogic animator so as to learn } \\
\text { how to be organised while hoping for } \\
\text { a higher post of responsibility like } \\
\text { pedagogic inspector. }\end{array}$ \\
\hline THREATS & Hila & WT Strategy \\
\hline $\begin{array}{l}\text {-attack from parents and } \\
\text { learners } \\
\text {-bias appointments } \\
\text {-poor carrier management } \\
\text {-threat from colleagues and } \\
\text { administration } \\
\text {-poor infrastructure } \\
\text {-overcrowded classes } \\
\text {-the pressure to implement } \\
\text { policies which do not fit in my } \\
\text { context of teaching } \\
\text {-the arrest and intimidation of } \\
\text { teacher by administrative } \\
\text { authorities out of education. } \\
\text {-parents pose to challenge } \\
\text { teachers in their practice } \\
\text {-criticisms from colleagues, } \\
\text { learners and the administration } \\
\text {-violence in the school milieu }\end{array}$ & $\begin{array}{l}\text {--have self confidence } \\
\text {-select the best actions to take in } \\
\text { the execution of pedagogic } \\
\text { practices } \\
\text {-interpersonal skills help in lesson } \\
\text { planning, delivery, class } \\
\text { management and collaboration } \\
\text { with colleagues } \\
\text {-use experience to adapt the } \\
\text { policies from hierarchy to suit the } \\
\text { context or working locality } \\
\text {-to minimize the threat from } \\
\text { overcrowded and large class sizes } \\
\text { employ interpersonal skills to get } \\
\text { the learners interact among } \\
\text { themselves to learn } \\
\text {-create interpersonal relationship } \\
\text { with the learners to gain their } \\
\text { interest to avoid conflicts that can }\end{array}$ & $\begin{array}{l}\text {-struggle to be hardworking to avoid } \\
\text { the confrontation with learners, } \\
\text { parents and administrators } \\
\text {-develop patience towards learners } \\
\text { and colleagues to work as a team for } \\
\text { the proper execution of pedagogic } \\
\text { practices } \\
\text {-struggle to have self-control over } \\
\text { anger to avoid conflicts and } \\
\text { confrontations with learners which } \\
\text { can stand as a threat. } \\
\text { - try to accept challenging tasks to } \\
\text { avoid being criticised to be an } \\
\text { unqualified teacher } \\
\text {-take the challenge to acquire } \\
\text { computer literacy skill to minimize } \\
\text { the threat from the pressure of using } \\
\text { media in pedagogic practices } \\
\text {-setting personal goals and the means }\end{array}$ \\
\hline
\end{tabular}


Using Teacher -SWOT Analyses as a Tool for Pedagogic Practice Efficiency: The Case of Some Selected English-Speaking Primary Schools in the Diamare Division, Far North Region of Cameroon

\begin{tabular}{|c|c|c|}
\hline $\begin{array}{l}\text {-poor working conditions } \\
\text {-downgrading of the teaching } \\
\text { profession }\end{array}$ & $\begin{array}{l}\text { be harmful to pedagogic practices } \\
\text {-exchange of knowledge on good } \\
\text { pedagogic practices with } \\
\text { colleagues reduces the mistakes } \\
\text { which can attract administrative } \\
\text { sanctions. } \\
\text {-professional consciousness give } \\
\text { the desire for self-actualisation or } \\
\text { fulfilment as a teacher and not } \\
\text { waiting for pressure and } \\
\text { impositions from the } \\
\text { administration a proper mastery of } \\
\text {-ensure a through } \\
\text { pedagogic practices } \\
\text { frequent research to minimize } \\
\text { threats learners } \\
\text {-teach and follow up the leare } \\
\text { very well so that they produce } \\
\text { good results for the parents and } \\
\text { administrators to have nothing to } \\
\text { base on for pressure in the exercise } \\
\text { of pedagogic practice by the } \\
\text { teacher. }\end{array}$ & $\begin{array}{l}\text { to achieve them for personal growth } \\
\text { in the teaching profession. } \\
\text {-individual empowerment through } \\
\text { research and development in } \\
\text { pedagogic practices }\end{array}$ \\
\hline
\end{tabular}

The TOWS matrix table above is cross examined in two main entry points. These entry ports are the internal factors which are strengths and weaknesses and the external factors which are opportunities and threats. These two entry ports can be evaluated in four aspects which will enable us verify our hypothesis. These four aspects according to Weihrich (1982) are: SO which is how the teacher uses the internal strengths to exploit external opportunities; ST which points out the use of internal strength to minimize the impact of external threats; WO which explains how teachers overcome internal weaknesses by exploiting external opportunities and finally WT that shows how teachers are overcoming internal weakness by minimizing external threats. From the data gathered in the field, the literature review and the Deci and Ryan(1985) theory of Self-determination theory (SDT) and analysing the matrix table we would be able to verify whether teachers SWOT analyses enhances their pedagogic practice or not.

From the SO strategy on the table above, it can be seen that the $90 \%$ male and $\mathbf{4 3 . 1} \%$ female teachers in the Diamare Division who do their SWOT analyses actually make use of their internal strengths to exploit external opportunities to enhance their pedagogic efficiency. They attest that, due to their internal strengths, they are able to go for further studies both professional and academic, maintain zeal and passion for teaching, do research and share knowledge, participate in pedagogic seminars and exchange ideas on best pedagogic practices. This is due to self-determination as put forth by Deci and Ryan(1985) in the Self-determination theory (SDT). These teachers want to perfect their pedagogic practices so it engineers an intrinsic motivation in them. From the responses got in the field as far as SO strategy is concerned we can confirm that teachers SWOT analyses enhances pedagogic efficiency.

The next aspect that is considered on the TWOS matrix table is the WO, which explains how teachers overcome internal weaknesses by exploiting external opportunities. At this level, we see how the teachers exploit learning opportunities to counter laziness, some seek transfer to areas where they will feel at ease to teach, due to the desire to be appointed the teachers are forced to work hard so as to be noticed by hierarchy, attend pedagogic seminars and workshops to help them overcome discouragement and laziness. When a teacher is discouraged it leads to laziness and poor pedagogic practice. That is why the $90 \%$ male and $\mathbf{4 3 . 1} \%$ female teachers who carry out their SWOT analyses do everything not to be pedagogically unproductive. By exploiting these opportunities they overcome their weaknesses and become efficient in their pedagogic practice. Ryan, Kuhl, and Deci (1997) quoted by Deci \& Ryan (2000.p.68) hold that SDT is an approach to human motivation and personality that uses traditional empirical methods while employing an organismic meta theory that highlights the importance of humans' evolved inner resources for personality development and behavioural self-regulation. As teachers exploit their opportunities to overcome the weaknesses, they are using their inner resources for their development. 
With respect to the ST strategy, it can be seen that $90 \%$ male and $\mathbf{4 3 . 1} \%$ female teachers who carry out SWOT use their internal strength to minimize the impact of external threats. Since threats can crush best pedagogic practices, they build self-confidence, select best actions to take in the execution of their pedagogic practices, collaborate with colleagues to exchange experiences on lesson planning, delivery, use of teaching aids, remediation, work in groups and do close follow up to create a conducive working climate with learners, parents and administrators so as to produce good results.

Finally, the analyses of the WT strategy, reveals that these $90 \%$ male and $43.1 \%$ female teachers who carry out SWOT have an intrinsic motivation. This intrinsic motivation come from the desire to improve on their pedagogic practice. Due to this, the teachers seek to overcome their internal weakness by minimizing external threats. They struggle to work hard in other to avoid criticisms, develop patience towards learners, build self-control to overcome anger, accept challenging tasks which serve as complements, acquire computer literacy skills and seek for other avenues of individual empowerment.

With an average of $62.2 \%$ of teachers who do SWOT analyses in the Diamare Division, as revealed by the TWOS matrix table we are made to understand that teachers make use of their internal factors of SWOT to overcome the external factors which are counter-productive. This makes us confirm our hypothesis that, SWOT analyses enhances teachers pedagogic practice efficiency. It is only intrinsic motivation that can spur a teacher to seek for ways to improve on their pedagogic practice.

\section{CONCLUSION}

SWOT analyses which have been frequently used to evaluate the internal functioning of institutions and organisations can also be used by individual teachers to self-evaluate their pedagogic practice to be efficient. For a teacher to decide to carry out a SWOT analyses of his or her activities, it takes a determination to change or improve on a behaviour which is determined by a motivational force. Deci \& Ryan, (2008) says that both intrinsic and extrinsic motivation are highly influential determinants of our behaviour, and both drive us to meet three basic human needs: firstly, competence which is the need to be effective in dealing with environment. Secondly, relatedness which focuses on need to have a close affectionate relationships with others and finally, autonomy which is the need to control the course of their lives. As the teacher is determined to gain autonomy in controlling the course of his or her pedagogic practice, teacher SWOT analyses is inevitable.

As proven by the data collected from the field, we noticed that as teachers of the English speaking schools in the Diamare Division are determined to be efficient in their pedagogic practice, they carry out SWOT analyses. This analyses shows that teachers actually make use of their internal strengths to exploit existing opportunities, use their internal strengths to minimize the impact of external threats, overcome internal weaknesses by exploiting external opportunities and finally, overcome internal weakness to minimize external threats in the course of their pedagogic practice to be efficient.

Concretely, through teachers SWOT analyses, teachers in the Diamare Division become more and more efficient in their pedagogic practice by being able: to select the best actions to take in the execution of pedagogic practices; to develop interpersonal skills in lesson planning, delivery, class management and collaboration with colleagues; to employ interpersonal skills to get the learners interact among themselves to learn; to create interpersonal relationship with the learners to gain their interest to avoid conflicts that can be harmful to pedagogic practices ; to exchange knowledge on good pedagogic practices with colleagues to reduce mistakes; to ensure a proper mastery of pedagogic practices through frequent research to minimize threats ; to maintain zeal and duty consciousness ; to carry out research; to exploit the passion for teaching by going for further professional training programmes in the carrier; to avoid laziness; to take the challenge to accept difficult and challenging pedagogic practices to fulfil administrative exigencies; to have self-confidence; to teach and follow up the learners very well so that they produce good results ; to struggle to be hardworking to avoid the confrontation with learners, parents and administrators ; to develop patience towards learners and colleagues to work as a team for the proper execution of pedagogic practices; to take the challenge to acquire computer literacy skills to be able to use media in pedagogic practices; set personal goals and the means to achieve them for personal growth in the teaching profession. In a nutshell, since this study reveals that teachers SWOT analyses greatly influence teachers' pedagogic efficiency it is recommend that all teachers should consciously and constantly carryout their SWOT analyses so as to constantly adjust their practices. 
Using Teacher -SWOT Analyses as a Tool for Pedagogic Practice Efficiency: The Case of Some Selected English-Speaking Primary Schools in the Diamare Division, Far North Region of Cameroon

\section{REFERENCES}

[1] David, F. (1997).Strategic management (6 ${ }^{\text {th }}$ ed.). Upper Saddle River, NJ: Prentice Hall.

[2] Deci, E. L., \& Ryan, R. M. (1985). Intrinsic motivation and self-determination in human behavior. New York: Plenum.

[3] Drucker, P. F. (2005, January). Managing oneself. Harvard Business Review. Web. Retrieved $14^{\text {th }}$ February 2020.

[4] Heihrich, H. (1982).The TOWS Matrix: A tool for situational analyses. Web. Retrieved $4{ }^{\text {th }}$ March 2020.

[5] Hyan, L.K (1993).Teacher self-evaluation, teacher in their own mirror. Boston District: Kluwer Academic Publishers.

[6] Kamelia, G. (2011). The SWOT Analysis: Process and Basic Components www.uj.edu.sa/.../Chapter\%2011 \%20SWOT\%20ANALYSIS.pdf. Web Retrieved $4^{\text {th }}$ March 2020.

[7] Margaret, C. (1997a).The effects of attitudes, pedagogical practices and teachers' role on the incoperation of ICT into the school curriculum. IFIP London: Chapman and Hall.

[8] MINESEC. (2013). Official syllabuses for teacher training colleges (T.T.C.). Yaoundé: CEPER S.A.

[9] Nkong, M.M.V . (2017). Teacher evaluation in ameliorating learning achievements: the case of basic education teachers in the south-west region of Cameroon. Phd thesis; University of maroua.

[10] Asuanteh, N.A. (2017). Pedagogic practice innovation and teachers' efficiency: The case of Government Bilingual Primary schools in the Maroua municipality. Masters dissertation; University of Maroua.

[11] Rand, A. (1957). Atlas Shrugged. New York: Random House.

[12] Robinson, A. (1980). Principles and practice of teaching. London: George Allen and Unwin LTD.

[13] Ryan, R. M., \& Deci, E. L. (2000). Self-determination theory and the facilitation of intrinsic motivation, social development, and well-being. American Psychologist. Web.

[14] Retrieved $10^{\text {th }}$ February 2020.

[15] Deci, E. L., \& Ryan, R. M. (1985). Intrinsic motivation and self-determination in human behavior. New York, NY: Plenum.

[16] Tambo, L. (2003). Principles and methods of teaching, applications in Cameroon schools.

[17] Buea: ANUCAM Publishers.

[18] Tsafack, G. (1998). Ethics and deontology in education. Yaounde: Press universitaires d'Afrique, Yaoundé.

[19] Wanjala, E. (2012).Level of teachers' efficiency in work performance in public secondary schools in WajirNorth District-Kenya. Masters thesis, Universityof Nairobi Kenya

Citation: Bachir Bouba, et.al. "Using Teacher-SWOT Analyses as a Tool for Pedagogic Practice Efficiency: The Case of Some Selected English-Speaking Primary Schools in the Diamare Division, Far North Region of Cameroon" International Journal of Humanities Social Sciences and Education (IJHSSE), vol 8, no. 4, 2021, pp. 146-156. doi: https://doi.org/10.20431/2349-0381.0804013.

Copyright: () 2021 Authors. This is an open-access article distributed under the terms of the Creative Commons Attribution License, which permits unrestricted use, distribution, and reproduction in any medium, provided the original author and source are credited. 